www.czasopisma.marszalek.com.pl/pl/10-15804/npw

\author{
TOMASZ R. DĘBOWSKI \\ Uniwersytet Wrocławski \\ ORCID ID: https://orcid.org/0000-0002-9933-8911
}

\title{
Zagrożenia dla bezpieczeństwa dzieci zamieszkujących w strefie konfliktu na wschodniej Ukrainie
}

\section{Threats to the safety of children in the conflict zone in eastern Ukraine}

\section{Abstract}

Publications on the conflict in eastern Ukraine rarely describe the situation of children living in the combat zone. More attention is paid to the political, economic and military aspects of this confrontation. The author has set himself two goals. The first one is to check how the war affects the biological and mental aspects of children's lives. The second is an attempt to answer the question whether there is a possibility of improving the situation of minors. The paper on the problematic system is divided into three parts.

The first part draws attention to the following problems: difficulties with access to medical care, increased incidence of infectious diseases, growing drug addiction, drinking water pollution, as well as the threat of unexploded ordnance. The second part describes: threats to mental health of children, socialization problems (pre-school and school education, family crisis, shaping of national identity), as well as participation of child soldiers in the conflict in Donbass. The last section of the article contains conclusions.

The considerations were prepared on the basis of carefully verified materials in English, Ukrainian and Polish. Many publications were downloaded from the websites of international organizations, analytical centers and scientific institutions.

Keywords: Donbass, war, conflict zone, children, threats, security 


\section{Угрозы безопасности детей в зоне конфликта на востоке Украины}

\section{Аннотачия}

В публикациях, посвященных конфликту на востоке Украины, редко описывается положение детей, живущих в зоне боевых действий. Больше внимания уделяется политическим, экономическим и военным аспектам этого противостояния. Автор поставил перед собой две цели. Первая - выяснить, как война влияет на биологические и ментальные аспекты жизни детей. Вторая цель - это попытка ответить на вопрос, есть ли возможность улучшить положение несовершеннолетних? Текст статьи состоит из трех частей.

В первой части обращается внимание на проблемы трудного доступа к медицинскому обслуживанию, роста заболеваемости инфекционными заболеваниями, роста наркомании, загрязнения питьевой воды, а также угрозы невзорвавшихся боеприпасов. Во второй части описываются угрозы психическому здоровью детей, проблемы социализации (дошкольное и школьное образование, семейный кризис, формирование национальной идентичности), а также участие детей-солдат в конфликте в Донбассе. Заключение статьи содержит выводы.

Размышления были подготовлены на основе тщательно подобранных материалов на английском, украинском и польском языках. Многие публикации были загружены с веб-сайтов международных организаций, аналитических центров и научных учреждений.

Ключевые слова: Донбасс, война, зона конфликта, дети, угрозы, безопасность

W konfliktach, które toczyły się w latach 2013-2017, zginęło 870 tys. dzieci do piątego roku życia. Był to wskaźnik pięciokrotnie wyższy od liczby bojowników, którzy ponieśli śmierć w walkach. W 2017 roku aż 420 mln. dzieci żyło w strefach działań zbrojnych, z czego $142 \mathrm{mln}$ w miejscach, które charakteryzowały się starciami o wysokiej intensywności. Egzystujący tam małoletni byli zagrożeni nie tylko utratą życia, zdrowia, dachu nad głową, głodem czy sieroctwem. To także ofiary porwań, tortur oraz przemocy seksualnej. W niektórych wypadkach dzieci wcielano do sił biorących czynny udział w działaniach zbrojnych. Na początku 2019 roku najtrudniejsza sytuacja nieletnich występowała w: Afganistanie, Republice Środkowoafrykańskiej, Demokratycznej Republice Konga, Iraku, Mali, Nigerii, Somalii, Południowym Sudanie, Syrii oraz Jemenie (Graham et. al., 2019, s. 9-10).W najbliższym sąsiedztwie Polski w 2017 roku ponad 56 tys. dzieci 
zagrożonych działaniami zbrojnymi zamieszkiwało tereny leżące wzdłuż 472-kilometrowej linii kontaktowej, w strefie konfliktu na wschodniej Ukrainie (Atman, 2018, s. 5).

Nadmieńmy, że w polskiej literaturze naukowej nie brakuje opracowań poruszających problematykę działań zbrojnych w tej części Europy. Przy czym prace te najczęściej ogniskują się wokół zagadnień wielowymiarowości konfliktu ukraińsko-rosyjskiego (Baluk, Doroszko, 2017), jego geopolitycznych uwarunkowań w kontekście rywalizacji Stanów Zjednoczonych, Rosji i Chin (Surdyk 2017) czy specyfiki rosyjskich działań militarnych i pozamilitarnych, podjętych wobec Kijowa (Pacek, 2018; Banasik, 2018). Nie eksplorują zatem spraw dotykających zagrożeń dla bezpieczeństwa dzieci zamieszkujących wzdłuż linii kontaktowej. Analogiczny wniosek nasuwa się po przeglądzie literatury dotyczącej sytuacji nieletnich, uwikłanych w działania zbrojne. Zdecydowana większość tych publikacji powstała przed końcem 2013 roku, co w praktyce wyklucza możliwość, aby mogły odnosić się do konfliktu na wschodzie Ukrainy. Z kolei w pracach wydawanych w następnych latach z oglądu wykluczono nieletnich żyjących w Europie (Ceneda-Miedzińska, 2018; Mormul, 2014, s. 245-274).

Powyższe przesłanki były czynnikami, który przesądziły o podjęciu przez autora starań zmierzających do zarysowania sytuacji nieletnich żyjących w strefie walk. Podkreślmy, że ze względu na wymogi dotyczące objętości tekstu, a także trudności w pozyskaniu wiarygodnego materiału badawczego, z oglądu wyłączone zostały dzieci znajdujące się pod całodobową opieką w placówkach opiekuńczo-wychowawczych typu socjalizacyjnego oraz w jednostkach świadczących usługi bytowe, opiekuńcze, wspomagające i edukacyjne dla osób obciążonych chorobami lub niepełnosprawnościami. Wstępna analiza zgromadzonego materiału badawczego pozwoliła na sformułowanie hipotezy roboczej: strony konfliktu na wschodzie Ukrainy nie są w stanie samodzielnie zapewnić bezpieczeństwa dzieciom żyjącym wzdłuż linii kontaktowej. Ponadto przyczyniła się do skrystalizowania dwóch pytań badawczych. Pierwszego: jakie są czynniki determinujące sytuację dzieci na tym obszarze? Drugiego: jakie powinny być spełnione przesłanki, aby poprawić położenie nieletnich w strefie kontaktowej?

W celu zrealizowania powyższego zamarzenia badawczego autor postanowił posłużyć się ujęciem jakościowym. Praca, będąca opracowaniem 
z zakresu bezpieczeństwa społecznego, odwołuje się do analizy socjologicznej konfliktu, z uwzględnieniem aspektów politologicznych. W tekście poddano badaniu materiały wtórne w językach: angielskim, ukraińskim i polskim, które pozyskano z wiarygodnych źródeł, np. organizacji międzynarodowych, fundacji, ośrodków analitycznych, instytucji naukowych itd. Podczas ich selekcji dołożono starań, aby wyeliminować publikacje, które miały znamiona materiałów o charakterze propagandowym. Tekst o układzie problemowym podzielono na trzy części. Pierwsza dotyka spraw zagrożeń dla biologicznej egzystencji małoletnich. W drugiej pochylono się nad wyzwaniami dla ich psychicznej kondycji. W ostatnim (trzecim) fragmencie publikacji przedstawione zostały wnioski.

\section{Zagrożenia dla biologicznej egzystencji dzieci}

Działania zbrojne oraz ich następstwa stanowią realne zagrożenia dla biologicznej egzystencji małoletnich. W strefie konfliktu na wschodzie Ukrainy zanotowano wzrastającą liczbę dzieci rodzących się z różnymi nieprawidłowościami, co jest spowodowane m.in. przewlekłym stresem, doświadczanym przez ciężarne kobiety. Ponadto pogorszeniu uległa dostępność do opieki neonatologicznej, przy jednocześnie nasilającym się zjawisku przemocy wobec kobiet (Verbovskaya, 2016a). Dodajmy, że od momentu wybuchu konfliktu liczba przypadków zarażenia wirusowym zapaleniem wątroby typu C oraz wirusem HIV uległa zwiększeniu na całym terytorium Ukrainy, a w szczególności w Doniecku i Ługańsku. Przy czym w Doniecku, który już przed zimą 2014 roku był miastem przodującym pod względem występowania tych problemów, liczba infekcji HIV wzrosła o 30\%, a w Ługańsku dwukrotnie (Vasylyeva, et. al., 2018). Powyższy problem dotyka również kobiet w wieku rozrodczym, zwiększając tym samym ryzyko przeniesienia infekcji na płód (Verbovskaya, 2016b). Szacunkowe dane wskazują, że na początku 2019 roku 73\% nowych zakażeń nastąpiło w konsekwencji różnych form aktywności seksualnej, a w szczególności o charakterze zarobkowym. Pozostałe przypadki związane są z przyjmowaniem narkotyków drogą iniekcji, które dla rozwijającego się zarodka stanowią dodatkowe zagrożenie.

Substancje psychoaktywne stanowią także niebezpieczeństwo dla dzieci w wieku szkolnym. Według szacunków Biura ONZ ds. Narkotyków 
i Przestępczości oraz doniesień ukraińskich dziennikarzy, rynek narkotykowy Donbasu zdominowany został przez narkotyki pochodzące z Rosji. Warto nadmienić, że jeszcze przed 2014 rokiem przez terytorium Ukrainy przechodził tranzyt narkotyków z „Azji Południowo-Zachodniej (Iran i Afganistan), Azji Środkowej (Kirgistan i Tadżykistan) oraz Kaukazu (Czeczenia, Gruzja i Azerbejdżan), przeznaczonych do Europy Wschodniej (głównie Węgry) i Europy Zachodniej: haszysz, opium, słoma makowa i heroina" (Shelley, 1998, s. 650). Obecnie w Donbasie poważny problem stanowią również substancje wytwarzane metodami chałupniczymi, np. z leków dostępnych bez recepty, poddanych obróbce chemicznej, w której używana jest benzyna, a także rozcieńczalniki, kwas solny, jod oraz fosfor. $W$ tym regionie najczęściej osoby uzależnione sięgały po: „Boltushkę” - do złudzenia przypominającą metkatynon, „Krokodyla” (dezomorfina) - silnie zanieczyszczoną pochodną morfiny, której receptura została opracowana na Syberii oraz „Shirkę”, która wytwarzana jest z suszu makowego, wzbogaconego lekami psychotropowymi (Marcinkowski, Motyka, 2014, s. 820).

Zdrowiu małoletnich w Donbasie, podobnie jak w innych częściach Ukrainy, nie sprzyjają zaniedbania w zakresie szczepień profilaktycznych. Jeszcze na początku ostatniej dekady XX wieku ich wskaźnik wynosił 100\%, ale w kolejnych latach systematycznie spadał, aż do poziomu 50\% w 2014 roku (Bachmaha, 2016). Podkreślmy, że brak szczepień jest czynnikiem znacząco wpływającym na częstotliwość występowania takich chorób, jak gruźlica, odra czy polio. W tym kontekście nie należy pomijać również oddziaływania takich czynników, jak: niedożywienie, zaniedbania w zakresie higieny, trudności z dostępem do leków oraz innych artykułów medycznych czy zbyt małej liczby wykwalifikowanego personelu medycznego (WHO, 2017).

Poważnym wyzwaniem jest również niewystarczający dostępu do czystej wody, w następstwie czego dzieci żyjące w strefie konfliktu zagrożone są chorobami biegunkowymi. Według szacunków UNICEF, właśnie z tego powodu nieletni poniżej 15. roku życia są trzy razy bardziej narażeni na śmierć niż z tytułu bezpośredniej przemocy. W wypadku dzieci do piątego roku życia wskaźnik ten jest dwudziestokrotnie wyższy. Przypomnijmy, że pod koniec września 2018 roku doszło do masowego zatrucia wodą pitną w Makiivce, w obwodzie donieckim (BBC, 2018). Z kolei UNICEF odnotował, że do początku 2019 roku na wschodzie Ukrainy miało miejsce 108 
przypadków ataków na obiekty infrastruktury wodnej (2019a, s. 3). Dodajmy, że zapewnieniu dostaw tego medium nie sprzyja również znaczny stopień wyeksploatowania sieci wodnej, której rodowód sięga końca lat 50. XX wieku. Działania zbrojne nie tylko przyczyniają się do pogorszenia jej stanu, ale także uniemożliwiają prace modernizacyjne. Podobnie wygląda sytuacja infrastruktury odpowiedzialnej za odprowadzenie i oczyszczanie ścieków (Lambroschini, 2018). O niezadowalającej jakości wody pitnej przesądza także znaczny stopień degradacji środowiska naturalnego w Donbasie. Przypomnijmy, że w tym regionie dominuje przemysł ciężki, który w procesach technologicznych wykorzystuje znaczne ilości tej cieczy, jednocześnie prowadząc do skażenia jej rezerwuarów (Tereshchenko, 2019). Ponadto, sytuację pogorszyły działania zbrojne, których następstwem są zdarzające się wycieki szkodliwych substancji chemicznych z uszkodzonej infrastruktury przemysłowej, w efekcie czego dochodzi do zanieczyszczenia nie tylko gleby i powietrza, ale także wód gruntowych. W tym miejscu warto przywołać szeroko komentowany w światowych mediach przypadek kopalni Junkom, obecnie znajdującej się pod kontrolą Donieckiej Republiki Ludowej, w której w 1979 roku przeprowadzono podziemną próbę nuklearną. Jej zatopienie w następstwie wyłączenia urządzeń odwadniających sprawi, że zalegające tam radioaktywne substancje mogą przeniknąć do wód gruntowych, a w konsekwencji zanieczyścić studnie, zbiorniki oraz rzekę Doniec, płynąca przez Donbas do Rosji (Andrusieczko, 2018).

Kolejnym istotnym wyzwaniem dla życia i zdrowia dzieci żyjących w Donbasie są eksplozywne pozostałości po walkach. UNICEF szacuje, że w strefie starć około 220 tys. dzieci narażonych jest na utratę życia lub zdrowia, w następstwie kontaktu z minami lądowymi, improwizowanymi ładunkami wybuchowymi, niewypałami oraz niewybuchami. Od zimy 2014 roku do kwietnia 2019 roku ofiarami min przeciwpiechotnych stało się 125 dzieci, z czego 27 poniosło śmierć (UNIAN, 2019). Obecnie Ukraina zajmuje trzecie miejsce po Syrii i Afganistanie pod względem liczby ofiar spowodowanych przez miny lądowe, które znajdują się w bezpośredniej bliskości osiedli, na terenach kontrolowanych przez strony konfliktu. Nadmieńmy, że w 2005 roku Kijów podpisał traktat ottawski (1999), jednakże Biuro Wysokiego Komisarza ONZ ds. Praw Człowieka w 2016 roku utrzymywało, 
że wojska rządowe, podobnie jak grupy separatystyczne, stosowały miny lądowe. Z kolei w 2018 roku organizacje pozarządowe International Campaign to Ban Landmines oraz Cluster Munition Coalition twierdziły, że tylko rebelianci posługiwali się tymi środkami bojowymi. Niedostatek danych ze źródeł niezależnych od stron konfliktu uniemożliwia określenie rzeczywistej odpowiedzialności wojsk rządowych i separatystów z tytułu wykorzystania min lądowych w strefie starć, w której pomimo zawartego rozejmu nadal dochodzi do wymiany ognia. Dodajmy, że w raporcie przygotowanym wiosną 2018 roku na zlecenie Fundacji Heinricha Boella wskazano, że przedstawiciele Specjalnej Misji Obserwacyjnej OBWE na Ukrainie w nieoficjalnych rozmowach zwracali uwagę na pewną specyficzną praktykę walczących stron. Polegała ona na usuwaniu min z terenów, które miały być poddane międzynarodowej inspekcji, a następnie - po jej zakończeniu - na ich ponownym zaminowywaniu (Ostatnina, 2018).

Do wypadków dzieci na skutek kontaktu z eksplozywnymi pozostałościami po walkach dochodzi najczęściej w sytuacji, gdy nieletni nie znajdują się pod opieką dorosłych. W ukraińskich i międzynarodowych mediach szeroko komentowano incydent w miejscowości Horlivka. Czwórka chłopców w wieku od 13 do 15 lat weszła na teren opuszczonej posesji w rejonie, w którym wcześniej prowadzone były starcia. W następstwie wyzwolenia urządzenia zapalającego doszło do wybuchu, który zabił troje dzieci, a czwarte zostało ciężko ranne (DW, 2018). Innym, często przywoływanym przypadkiem, jest historia czternastoletniego Alieksieja z Vozdvyzhenka. Chłopiec podniósł z ziemi przedmiot przypominający długopis, który wypadł z samochodu przewożącego sprzęt wojskowy. Najprawdopodobniej był to zapalnik do granatu, który eksplodując urwał trzy palce w jego prawej dłoni (Sharpe, 2018). Dodajmy, że także dorośli opiekunowie małoletnich stają się ofiarami podobnych incydentów. Śmierć lub kalectwo rodziców istotnie wpływają na jakość egzystencji dzieci. I tak, np. małoletni po zgonie ojca lub w następstwie jego niepełnosprawności, muszą podjąć pracę, aby zapewnić przetrwanie rodzinie, co $\mathrm{w}$ wielu wypadkach prowadzi do przerwania nauki. Z kolei śmierć matki sprawia, że dzieci są rzadziej żywione we właściwy sposób, nie przystępują do szczepień, a także częściej padają ofiarami wyzysku (UNICEF, 2004). 


\section{Zagrożenia dla sfery psychicznej dzieci}

Dzieci zamieszkujące w strefie konfliktu w najgłębszym stopniu doświadczyły skutków wojny (zob. Adamczyk, 2016, s. 134-135). U części z nich występuje zespół stresu pourazowego (PTSD - posttraumatic stress disorder), czyli przewlekłego zaburzenia psychicznego, związanego z ekspozycją na traumatyczne bodźce. Wyraża się ono m.in. w zaburzeniach zachowania i komunikacji, agresji, stanach lękowych, fobiach czy trudnościach z nauką. Obecnie, ze względu na sytuację panującą na wschodzie Ukrainy, przeprowadzenie kompleksowych badań, które pozwoliłyby oszacować skalę tego problemu, jest trudne. Zaznaczmy, że pomiary prowadzone w innych rejonach świata, w których dochodziło do starć zbrojnych, wykazały, iż PTSD jest obecny u około 47\% nieletnich (McLaughlin et. al., 2017, s. 281). Cząstkowy sondaż, który przeprowadzono na grupie blisko 500 małoletnich w strefie konfliktu, znajdującej się pod kontrolą Kijowa, przyniósł następujące wyniki:

- 25\% dzieci wykazywało ciężkie objawy PTSD, przy czym w tej grupie częściej doświadczają go dziewczynki niż chłopcy, na co wpływa m.in. relatywnie wysokie poczucie zagrożenia agresją seksualną, która nie sprowadza się wyłącznie do wypadków zgwałceń czy wielorakich form molestowania seksualnego. Podkreślmy, że Biuro Wysokiego Komisarza Narodów Zjednoczonych do spraw praw człowieka, w raporcie obejmującym lata 2014-2017 wskazywało również na przypadki wymuszeń rozbójniczych, dokonywanych przez część grup zbrojnych działających w Donieckiej Republice Ludowej i Ługańskiej Republice Ludowej, podczas których używano gróźb zgwałcenia żony i/lub małoletniej córki (OHCHR, 2017, s. 4). Z kolei w raporcie Gender and conflict in Ukraine (2017) zwrócono uwagę na przypadki podejmowania aktywności seksualnej przez dziewczęta żyjące w strefie konfliktu, w celu zdobycia środków niezbędnych do przetrwania ich oraz najbliższej rodziny (Lucas, Rohwerder, Tull, 2017, s. 5). Podkreślmy, że sprawa prostytucji nieletnich wzbudziła również zainteresowanie Departamentu Stanu USA. Jego pracownicy stwierdzili, że dziewczęta i kobiety porywane w Donbasie są wykorzystywane seksualnie na Ukrainie i w Rosji (VCHASNOUA, 2017); 
- u 31\% dzieci w przedziale wiekowym od 9 do 11 lat wystąpiły ciężkie objawy zespołu PTSD;

- u 24\% dzieci w przedziale wiekowym od 12 do 17 lat wystąpiły ciężkie objawy zespołu PTSD;

- 86,1\% respondentów widziało transporty wojskowe, $43 \%$ słyszało wystrzały i doświadczyło osobistego zagrożenia, $37 \%$ było świadkami starć zbrojnych, a ponad 8\% dzieci było świadkami zabijania obcych (szerzej Богданов, et. al., 2017, s. 44 i n.)ํ.

Nadmieńmy, że zaburzenia związane z PTSD dotykają również rówieśników nieletnich oraz ich dorosłych opiekunów, warunkując tym samym w sposób pośredni sytuację dzieci. Matthew Hodes z Imperial College London, prowadząc badania nad tym problemem, dowiódł że PTSD występujący u matki przyczynia się u dzieci do zachwiania poczucia trwałości związku $\mathrm{z}$ nią. Ponadto zaburzenia psychiczne rodziców, a w tym ich nieprzewidywalne zachowania sprawiają, że nieletni tracą oparcie w swoich opiekunach. Konsekwencją powyższego stanu rzeczy jest niższa samoocena dzieci, samookaleczenia, alkoholizm, zaburzenia empatii, czy większa częstotliwość występowania zachowań agresywnych wobec innych. Te ostatnie przyjmują postać np. znęcania się nad rówieśnikami w środowisku szkolnym, a także przemocy w Internecie (cyberbullying) (Bogatyreva, Winkler, 2018).

Warunki, w jakich wzrastają małoletni, znacząco wpływają na ich socjalizację, która w klasycznym ujęciu jest „procesem dziedziczenia stabilnej hierarchii wartości, w trakcie którego młody człowiek nabywał umiejętności, umożliwiające mu prawidłowe funkcjonowanie w środowisku społecznym, w którym żył" (Juszczyk-Rygałło, 2016, s. 15). Podkreślmy, że w wypadku samozwańczych republik w Donbasie, w latach, które upłynęły od wybuchu konfliktu, zaczęło kształtować się nowe pokolenie, nieznające realiów funkcjonowania w państwie, jakim była Ukraina przed zimą 2014 roku. Badania przeprowadzone przez Ukrainian Institute of Research of Extremism wykazały, że wojna popularyzuje agresję oraz brutalne metody rozwiązywania problemów. Ponadto dyskredytuje moralne standardy spokojnego życia,

1 Badanie przeprowadzili pracownicy Centrum Zdrowia Psychicznego i Wsparcia Psychicznego, działającego w ramach Narodowego Uniwersytetu „Akademii Kijowsko-Mohylańskiej”, na grupie 446 dzieci w 32 szkołach. 
podważa autorytet norm prawnych, dezawuuje kompromis i dialog jako środki do osiągania celu. Niewątpliwie dzieci socjalizowane w takich właśnie warunkach w przyszłości tworzyć będą społeczeństwo charakteryzujące się odmienną niż obecnie kulturą polityczną oraz innym stosunkiem do państwa i całego narodu (UIOROE, 2015, s. 6 i n.)

Zważywszy na to, że kluczową rolę w procesach socjalizacyjnych odgrywa rodzina, śmierć bliskich lub ich kalectwo istotnie determinuje ich przebieg, podobnie zresztą jak utrata dotychczasowego miejsca zamieszkania, czemu niejednokrotnie towarzyszy zakłócenie lub przerwanie relacji z rówieśnikami. Nie należy pomijać również faktu, że konflikt na wschodzie Ukrainy, który ma oznaki wojny domowej, skutkuje powstawaniem podziału ideologicznego, przebiegającego wzdłuż linii rozdzielającej wartości rosyjskie od ukraińskich, co w wypadku części rodzin, a zwłaszcza tych żyjących w Donbasie, prowadzi do zakłócenia związków dzieci z bliskimi. Vitalii Lunov analizując ten problemem zauważył, że dotyka on nawet małżonków. Rodzice, forsując swoje odmienne racje, nie biorą po uwagę uczuć dziecka, zatem „wprogramowują” w nieletnich swoją nienawiść (2015).

Istotną rolę w rozwoju psychospołecznym dziecka odgrywa edukacja przedszkolna i szkolna. UNICEF szacuje, że w wyniku działań wojennych po obu stronach linii kontaktowej, od początku konfliktu zostało uszkodzonych lub zniszczonych około 750 placówek. Powtarzające się incydenty zbrojne zakłócają ich funkcjonowanie, gdyż dzieci muszą opuszczać sale i szukać schronienia w piwnicach lub podziemnych schronach. W konsekwencji tych wypadków są zbyt przerażone, aby się dalej uczyć. Dodajmy, że nawet wówczas, gdy nie ma ostrzału, małoletni przebywają w zniszczonych pomieszczeniach, ze ścianami pokrytymi śladami po kulach, których okna zostały zabezpieczone workami z piaskiem. Zdarza się również, że te miejsca nie są ogrzewane z powodu uszkodzenia systemów wytwarzania, dostarczania i dystrybucji ciepła. Problemy z ogrzewaniem sal prowadzą do skrócenia zajęć lub ich całkowitego przerwania (UNICEF, 2019). Dla uczniów traumatyzującym doświadczeniem jest także konieczność przemieszczania się do szkół przez tereny, na których dochodzi do wymiany ognia oraz znajdują się eksplozywne pozostałości po walkach.

Analizując problematykę socjalizacji dzieci należy również zwrócić uwagę na sprawę kształtowania ich tożsamości narodowej, zarówno w wymiarze 
jednostkowym, jak i zbiorowym. W strefie konfliktu, podobnie jak na Krymie, podjęte zostały działania utrudniające przypisanie nowonarodzonym dzieciom obywatelstwa ukraińskiego. Polegają one na nieudostępnianiu rodzicom dokumentacji szpitalnej, co znacznie komplikuje uzyskanie ukraińskiego aktu urodzenia. Ponadto zdarzały się wypadki, gdy ukraińska administracja odmawiała uznania dokumentów wydawanych na terenach kontrolowanych przez separatystów (ECOIN, 2017).W stosunku do dzieci w wieku przedszkolnym i szkolnym prowadzona jest kampania edukacji patriotycznej, wzorowana na rosyjskich rozwiązaniach, przyjętych przez Moskwę w 2015 roku, w której kluczową rolę odgrywa nauczanie historii. Duży nacisk kładziony jest na prezentowanie „faszystowskiego wizerunku Ukrainy", gloryfikację Wielkiej Wojny Ojczyźnianej (1941-1945) oraz radzieckiego wkładu w walkę z faszyzmem (Abibok, 2018, s. 5). W programie Edukacja patriotyczna dzieci i młodzieży Donieckiej Republiki Ludowej (2017) przewidziano szkolenie wojskowe nieletnich $\mathrm{w}$ wieku przedpoborowym. Ma ono w przyszłości zaowocować ich wstąpieniem do sił zbrojnych „republiki”, ale także zachęcić do uczestniczenia w jej życiu politycznym. Dodajmy, że przejawy „miękkiej militaryzacji” dzieci pojawiają się również w edukacji przedszkolnej. Analogiczne działania wobec nieletnich podejmowane są także w Ługańskiej Republice Ludowej (Matviyishyn, 2019). Bez wątpienia takie formy edukacji patriotycznej mogą prowadzić do osłabienia istniejącej już tożsamości narodowej nieletnich, u których proces jej kształtowania zainicjowany został jeszcze w okresie poprzedzającym wybuch konfliktu na wschodzie Ukrainy. W tym miejscu warto zaznaczyć, że badania prowadzone przez Siergieja Savchenko i Vitalija Kurylo wykazały, iż długoletnie zaniedbania w zakresie edukacji patriotycznej na Ukrainie doprowadzily do sytuacji znacznego osłabienia poczucia związku mieszkańców Donbasu $\mathrm{z}$ całą wspólnotą państwową. To z kolei skutkowało ich społeczną obojętnością, a nawet wrogim nastawieniem do własnego kraju, który znalazł się w krytycznej sytuacji $(2018$, s. 1122). Analizując przyczyny podatności mieszkańców Donbasu na rosyjską propagandę należy podkreślić, że jest to złożony splot wielorakich czynników. Bez wątpienia należy wskazać na nostalgię starszego pokolenia za czasami ZSRR, a więc okresem „rządów silnej ręki”, gdzie o wszystkim decydowali urzędnicy. Ponadto, głęboką nienawiść donbaskiej młodzieży do wszystkiego, co ukraińskie. Młodych ludzi, będących 
świadkami wyczerpującej pracy swoich rodziców za niewspółmiernie niskie wynagrodzenia, egzystującej w państwie, w którym niewielka i bardzo bogata elita posiadała realną władzę (Zimmerman, 2018). Nie można pominąć także błędów popełnionych w zakresie prowadzenia oficjalnej ukraińskiej narracji narodowej. Od 1991 roku nowa elita starała się przeforsować własną wizję historii, w której centrum znajdował się naród, a zwłaszcza postulat walki narodowowyzwoleńczej. Zabrakło w niej natomiast miejsca dla „dumy z okresu Romanowów" i wykluczono z niej czasy radziecko-bolszewickie uznano je za okres okupacji. W opinii ówczesnych ideologów - co trafnie zauważa Wasyl Racewycz - koncepcja walki narodowowyzwoleńczej nie mogła zawrzeć w sobie zwycięskiego udziału Ukraińców w Wielkiej Wojnie Ojczyźnianej. Znalazło się w niej jednak miejsce dla batalionów „Nachtigall” i „Roland”, UPA, a nawet Dywizji SS Galizien (Racewycz, 2014, s. 30).

Konflikt zbrojny na wschodzie Ukrainy istotnie zwiększył ryzyko uczestniczenia dzieci w formacjach zbrojnych. Przed rozpoczęciem starć rekrutacja do nich nieletnich nie była uważana za poważany problem. W związku z powyższym w prawodawstwie ukraińskim istniała luka dotycząca tej kwestii. Do 2017 roku Międzynarodowy Komitet Czerwonego Krzyża w konflikcie na wschodzie Ukrainy udokumentował 95 wypadków pośredniego i bezpośredniego zaangażowania dzieci w działalność grup zbrojnych, z których 85 miało miejsce na terytoriach znajdujących się poza kontrolą Kijowa. Ponadto wskazał, że jest w stanie dowieść zaistnienia 32 sytuacji, które można zakwalifikować jako zbrodnie wojenne w świetle artykułu ósmego Rzymskiego Statutu Międzynarodowego Trybunału Karnego (1998). W 24 wypadkach - czytamy w raporcie - nieletni żołnierze nie przekroczyli 15 roku życia, a w ośmiu istniało znaczne prawdopodobieństwo wystąpienia analogicznego stanu rzeczy. Ponadto, pracownicy tej organizacji zidentyfikowali 200 dzieci z terenów nadzorowanych przez rebeliantów, które szkolono w rosyjskich obozach wojskowych lub na obszarach kontrolowanych przez Kreml (Abchazja, Krym) (CJFPID, s. 8-10). Analogiczny wątek obecny jest w raporcie Involvement of children in armed formations during the military conflict in Donbas, przygotowanym przez koalicję ukraińskich organizacji pozarządowych, współpracujących z Helsińską Fundacją Praw Człowieka. Wskazano w nim m.in., że obozy wojskowe dla młodzieży organizowane są po obu stronach konfliktu, przy czym na terenach niekontrolowanych przez Ukrainę 
jest ich więcej. Ponadto zwrócono uwagę na fakt, że młodociani rekruci byli uczeni nie tylko obsługi broni strzeleckiej, ale także taktyki walki, zasad kamuflażu oraz umiejętności instalowania min, a także ich dezaktywowania (HFHR, 2016, s. 3).

\section{Wnioski}

Odtworzenie pełnego obrazu sytuacji dzieci żyjących w strefie przylegającej do linii kontaktowej jest przedsięwzięciem trudnym do zrealizowania. Podkreślmy, że prowadzeniu badań na tym obszarze nie sprzyjają starcia zbrojne, które pomimo licznych deklaracji zawieszenia broni trwają nadal. Ponadto uczestniczące w nim strony nie są zainteresowane tym, aby pewne dane zostały upublicznione ze względu na to, że dopuszczały się działań, które miały znamiona zbrodni wojennych, na co zwrócił uwagę m.in. urząd Wysokiego Komisarza Narodów Zjednoczonych do spraw Praw Człowieka (TVN24, 2017). Konfliktowi towarzyszą również szeroko zakrojone zabiegi dezinformacyjne (wojna informacyjna i sieciowa), które są adresowane nie tylko do opinii publicznej Rosji i Ukrainy, ale także innych państw (Darczewska, 2014, s. 13 i n.).

Czynniki stanowiące negatywne bezpośrednie i pośrednie wyzwania dla biologicznego aspektu egzystencji dzieci mają dwojaki charakter. Pierwszą grupę stanowią determinanty, które występowały w Donbasie, zanim jeszcze doszło do starć zbrojnych. Nie ulega wątpliwości, że konflikt znacząco spotęgował ich oddziaływanie. Drugi zbiór to wielorakie zagrożenia, będące konsekwencją zastosowania techniki wojskowej.

Wojna na wschodzie Ukrainy odciska również swoje destrukcyjne piętno na psychice małoletnich, pozostawiając $\mathrm{w}$ niej trwałe traumatyczne ślady, ale także zaburzając proces socjalizacji. Niepokój budzi także stosowana przez strony konfliktu praktyka ideologicznego kształtowania dzieci według wzorców tworzących oraz utrwalających negatywne wyobrażania o ludziach zamieszkujących po przeciwnej stronie linii kontaktowej. W przyszłości te właśnie treści mogą utrudniać proces pojednania pomiędzy obecnymi stronami konfliktu, a także pogłębiać poczucie obcości.

Poprawa losu małoletnich, żyjących wzdłuż linii kontaktowej, wymaga w pierwszej kolejności całkowitego wstrzymania, a następnie trwałego 
zaniechania wymiany ognia pomiędzy walczącymi stronami. Ten wariant rozwoju wypadków wydaje się trudny do osiągnięcia, ale nie niemożliwy. Zdaniem Julii Abibok

Brak porozumienia między z jednej strony Zachodem i Ukrainą, a z drugiej Rosją, co do kwestii rozmieszczenia w Donbasie kontyngentu sił pokojowych ONZ, nie pozostawia nadziei na szybkie rozwiązanie konfliktu. Dlatego w najbliższych latach region ten prawdopodobnie nadal będzie się znajdował w stanie pełzającego konfliktu zbrojnego $(2018$, s. 7).

Podkreślmy, że w interesie Kremla leży utrzymanie Kijowa w swojej strefie wpływów. Moskwa, przyczyniając się do destabilizacji Donbasu, osłabiła szanse Ukrainy na integrację z Unią Europejską, a w dalszej perspektywie na jej wstąpienie do NATO (Zięba, 2015, s. 11). Ponadto rosyjskie władze zdają sobie sprawę z tego, że obecnie na niekorzyść Kijowa działa malejące zainteresowanie Zachodu konfliktem, który doprowadził do zamrożenia relacji gospodarczych, szczególnie istotnych dla Paryża i Berlina. Jak również, że amerykańska administracja widzi w Moskwie potencjalnego sojusznika w rozgrywce z Iranem i Chinami. Powyższe przesłanki sprawiają, że zwiększa się prawdopodobieństwo „powrotu do robienia wspólnych interesów”, a zatem zniesienia sankcji, które otworzą drogę Rosji do wyjścia z ekonomicznej stagnacji. Kluczem do zmiany sytuacji na Ukrainie, a co za tym idzie także na terenach objętych konfliktem, jest w opinii Jerzego Marka Nowakowskiego z Ośrodka Analiz Strategicznych „porzucenie przez Ukraińców twardej polityki antyrosyjskiej w połączeniu z deklarowaniem sympatii europejskich i stworzenie rządu uległego wobec Moskwy, a jednocześnie mającego wizerunek prozachodni” (Nowakowski, 2019).

Zważywszy na kondycję ekonomiczną Ukrainy oraz terenów, nad którymi Kijów utracił kontrolę, a także skalę problemów występujących w strefie konfliktu, strony starć nie są w stanie znacząco wpłynąć na poprawę jakości życia dzieci. Także i te przesłanki wyraźnie wskazują na konieczność podjęcia działań, w które będą zaangażowane inne państwa, w tym też Rosja. Dotyczy to zwłaszcza spraw związanych z zagrożeniami ekologicznymi, żywnościowymi, zdrowotnymi oraz kryminalnymi. Dotychczasowa akcja humanitarna, prowadzona $\mathrm{w}$ regionie przez międzynarodowe organizacje pozarządowe, 
pozwala tylko częściowo złagodzić problemy dotykające nieletnich. Skuteczne i kompleksowe wyeliminowanie np. zagrożeń ze strony min lądowych czy improwizowanych ładunków wybuchowych, oprócz woli politycznej wymaga pracy profesjonalnego personelu, wyposażonego w specjalistyczny sprzęt, którym dysponują pododdziały wojsk inżynieryjnych. Z kolei efektywne ograniczenie napływu substancji psychoaktywnych do Donbasu nie jest możliwe bez współpracy rosyjskich i ukraińskich służb odpowiedzialnych za zwalczanie przestępczości narkotykowej, a także międzynarodowej pomocy ze strony np. Interpolu. W świetle powyższych ustaleń należy stwierdzić, że w znacznej mierze udało się potwierdzić zasadność przyjętej hipotezy roboczej, jak również udzielić odpowiedzi na towarzyszące jej pytania badawcze.

PROF. TOMASZ R. DĘBOWSKI

Instytut Studiów Międzynarodowych

Wydział Nauk Społecznych

Uniwersytet Wrocławski

ul. Koszarowa 3, 51-149 Wrocław

tomasz.debowski@uwr.edu.pl

\section{Bibliografia}

Abibok, J. (2018). Na drodze do stworzenia „narodu Donbasu”. Polityka tożsamości samozwańczych republik na wschodzie Ukrainy. Komentarze OSW, 270, 1-7.

Adamczyk, M. (2016). Wojna rosyjsko-ukraińska w Donbasie jako wyzwanie dla chińskiej dyplomacji. Wschodnioznastwo, 133-144.

Andrusieczko, P. (2018, 15 maja). Pogrą̇̇onemu w wojnie Donbasowi grozi katastrofa ekologiczna. Pobrane z https:/www.euractiv.pl/section/energia-i-srodowisko/news/ pograzonemu-w-wojnie-donbasowi-grozi-katastrofa-ekologiczna.

Atman, J. (2018). The Children of the Contact Line in East Ukraine. 2017 Assessment Update. Pobrane z https://www.unicef.org/ukraine/media/451/file/report_1.pdf.

Bachmaha, M. (2016, październik). Vaccination Crisis in Ukraine: Its Origins and Consequences. Pobrane z https://krytyka.com/en/ukraines-public-health-challenge/ articles/vaccination-crisis-ukraine-its-origins-and-consequences.

Baluk, W., Dorosko, M. (red.). (2017). Wojna hybrydowa Rosji przeciwko Ukrainie w latach 2014-2016. Lublin: Wydawnictwo UMCS.

Banasik, M. (2018). Wojna hybrydowa i jej konsekwencje dla bezpieczeństwa euroatlantyckiego. Warszawa: DIFIN. 
Bogatyreva, E., Winkler, A. (2018, 15 stycznia). Meeting review - Global Mental Health Day: Mental Health in Conflict and War. Pobrane z https://www.med.uio.no/helsam/ english/research/centres/global-health/news-and-events/news/2017/global-mental-health-day-report.html.

British Broadcasting Company (BВC) (2018, 27 września). Массовое отравление в Макеевке: причина - питьевая вода. Pobrane z https://www.bbc.com/ukrainian/ news-russian-45664268.

Ceneda-Miedzińska, K. (2018). Wpływ konfliktu zbrojnego na bezpieczeństwo dzieci w Islamskiej Republice Afganistanu w latach 2004-2014. Kraków: Wydawnictwo Naukowe Uniwersytetu Pedagogicznego w Krakowie.

Coalition "Justice for Peace in Donbas" (CJFPID) (2017). Submission from the Coalition "Justice for Peace in Donbas" to the UPR. Coalition "Justice for Peace in Donbas": Kijów.

Darczewska, J. (2014). Anatomia rosyjskiej wojny informacyjnej. Operacja krymska studium przypadku. Punkt Widzenia, 42, 1-36.

Deutsche Welle (DW) (2018, 30 września). Schoolchildren killed by landmine in eastern Ukraine. Pobrane z https://www.dw.com/en/schoolchildren-killed-by-landmine -in-eastern-ukraine/a-45699040-0.

European Country of Origin Information Network (ECOIN) (2017, 3 marca). Country Report on Human Rights Practices 2016 - Ukraine. Pobrane z https://www.ecoi.net/ en/document/1394892.html.

Graham, G. et al. (2019). Stop the War on Children report. Londyn: Save the Children.

Helsinki Foundation for Human Rights (HFHR) (2016). Involvement of children in armed formations during the military conflict in Donbas. Warszawa: Helsinki Foundation for Human Rights.

Juszczyk-Rygałło, J. (2016). Socjalizacja dziecka jako proces kształtowania tożsamości. Edukacja Elementarna w Teorii i Praktyce, 4 (42), 13-25.

Kurylo, V., Savchenko, S. (2018). Patriotic Education in the Process of Youth Socialization in Conditions of Hybrid Warfare. The Journal of Social Sciences Research, 5, 1121-1125.

Lambroschini, S. (2018, 17 października). War and water in the Donbas. Pobrane $\mathrm{z}$ https://en.zois-berlin.de/publications/zois-spotlight-2018/war-and-water-in-the -donbas/? $\mathrm{L}=0$.

Lucas, B., Rohwerder, B., Tull, K. (2017). Gender and conflict in Ukraine. K4D Helpdesk Report. Brighton, UK: Institute of Development Studies, 1-17.

Lunov, V. (2015, 12 lipca). Children's Rights in the Donbas: Challenge of Psychology of Peace. Pobrane $\mathrm{z}$ https://papers.ssrn.com/sol3/papers.cfm?abstract_id=2629518.

Marcinkowski, J.T., Motyka, M. (2014). Nowe metody odurzania się. Cz. IV. Shisha i Boltushka. Problemy Higieny i Epidemiologii, 95 (4), 816-822.

Matviyishyn, I. (2019, 3 maja). Children as a Tool: How Russia Militarizes Kids in the Donbas and Crimea. Pobrane z https://www.atlanticcouncil.org/blogs/ukrainealert/ children-as-a-tool-how-russia-militarizes-kids-in-the-donbas-and-crimea.

McLaughlin, K.A. et al. (2017). Posttraumatic stress disorder in children and adolescents: Epidemiology, pathogenesis, clinical manifestations, course, assessment, and diagnosis. The British Journal of Psychiatry, 211, 280-288. 
Mormul, J. (2014). Problem łamania praw człowieka w państwach dysfunkcyjnych. Przypadek dzieci-żołnierzy. W: R. Kłosowicz (red.). Państwa dysfunkcyjne i międzynarodowe wysitki zmierzajace do ich naprawy (245-274). Kraków: Wydawnictwo Uniwersytetu Jagiellońskiego.

Nowakowski, J.M. (2019, 21 czerwca). Nowa Jałta czyli koniec polskiej polityki wschodniej. Pobrane z https://oaspl.org/2019/06/21/nowa-jalta-czyli-koniec-polskiej-polityki -wschodniej.

Ostatnina, E. (2018, 17 lipca). Landmines in the Donbass conflict zone: threats for the population and the necessity of mine clearance. Pobrane $\mathrm{z}$ https://www.boell.de/ en/2018/07/17/landmines-donbass-conflict-zone-threats-population-and-necessity-mine-clearance.

Pacek, B. (2018). Wojna hybrydowa na Ukrainie. Warszawa: Oficyna Wydawnicza RYTM. Racewycz, W. (2014). Kiełbasa to kiełbasa. Nowa Europa Wschodnia, 5, $27-33$.

Sharpe, M. (2018, 9 stycznia). Aleksey: Wounded for life by weapons of war. Eastern Ukraine is now one of the most mine-contaminated places on earth. Pobrane $\mathrm{z}$ https://www. unicef.org/eca/stories/aleksey-wounded-life-weapons-war.

Shelley, L.I. (1998). Organized Crime and Corruption in Ukraine: Impediments to the Development of a Free Market Economy. Demokratizatsiya, 4, 648-663.

Surdyk, K. (2017). Konflikt ukraiński w rozgrywkach geopolitycznych. Warszawa: DIFIN. Tereshchenko, Е. (2019, 27 luty), Екологічна катастрофа: чому половина території Донбасу може стати непридатною для життя. Pobrane z https://hromadske. radio/publications/ekologichna-katastrofa-chomu-polovyna-terytoriyi-donbasu-mozhe-staty-neprydatnoyu-dlya-zhyttya.

TVN24 (2017, 17 lutego). Alarmujący raport ONZ. Przemoc seksualna, tortury i napaści w Donbasie. Pobrane z https://www.tvn24.pl/wiadomosci-ze-swiata,2/onz-strony-konfliktu-w-donbasie-podejrzane-o-zbrodnie-wojenne,716292.html.

Ukrainian Independent Information Agency of News (UNIAN) (2019, 3 kwietnia). Nearly 270 civilians, incl. 27 children, killed in landmine blasts in Donbas since beginning of war. Pobrane z https://www.unian.info/war/10504236-nearly-270-civilians-inc1-27-children-killed-in-landmine-blasts-in-donbas-since-beginning-of-war.html.

Ukrainian Institute of Research of Extremism (UIOROE). (2015). Children of war. Research on problems of childhood in Ukraine in conditions of military aggression. Kijów: Ukrainian Instutiute of Reserch of Extremism.

United Nations Children's Fund (UNICEF) (2004, 2 grudnia). Landmines pose gravest risk for children. Pobrane $\mathrm{z}$ https://www.unicef.org/media/media_24360.html.

United Nations Children's Fund (UNICEF) (2019a, marzec). Water under Fire. Pobrane z https://www.unicef.ch/sites/default/files/2019-03/Report_Water-under-Fire_2019. pdf.

United Nations Children's Fund (UNICEF). (2019b, 20 maja). Attacks on schools quadruple in conflict-hit eastern Ukraine - UNICEF. Pobrane z https://www.unicef. org/press-releases/attacks-schools-quadruple-conflict-hit-eastern-ukraine-unicef.

United Nations High Commissioner for Human Rights (OHCHR) (2017, 27 lutego). Conflict-Related Sexual Violence in Ukraine 14 March 2014 to 31 January 2017. Pobrane z https://www.ohchr.org/Documents/Countries/UA/ReportCRSV_EN.pdf. 
Vasylyeva, T.I. i in. (2018, 16 stycznia). Molecular epidemiology reveals the role of war in the spread of HIV in Ukraine. Pobrano z: https://www.ncbi.nlm.nih.gov/pmc/ articles/PMC5798316/?tool=pubmed.

VCHASNOUA News Agency (VCHASNOUA) (2017, 27 czerwca). In the Donbass, Women and Girls Are Kidnapped for the Purpose of Sexual Exploitation, - the Report of the U.S. Department of State. Pobrane $\mathrm{z}$ https://vchasnoua.com/en/63-in-the-donbass-women-and-girls-are-kidnapped-for-the-purpose-of-sexual-exploitation-the-report-of-the-u-s-department-of-state.

Verbovskaya, М. (2016а, 20 mаја). Жінки й діти в зоні конфлікту. Частина 1. Pobrane $\mathrm{z}$ https://povaha.org.ua/zhinky-j-dity-v-zoni-konfliktu-chastyna-1.

Verbovskaya, M. (2016b, 23 mаја). Жінки й діти в зоні конфлікту. Частина 2. Pobrane z https://povaha.org.ua/zhinky-j-dity-v-zoni-konfliktu-chastyna-2.

World Health Organization (WHO) (2017, 3 września). Health response to the humanitarian crisis in Ukraine. Pobrane $\mathrm{z}$ http://www.euro.who.int/en/health -topics/ emergencies/health-response-to-the-humanitarian-crisis-in-ukraine/healthresponse-to-the-humanitarian-crisis-in-ukraine.

Zięba, R. (2015). Ukraina jako przedmiot rywalizacji między Zachodem a Rosją. Środkowoeuropejskie Studia Polityczne, 3, 5-26.

Zimmerman, V. (2018, 13 lipca), Why the Donbas Is So Vulnerable to Russian Propaganda. Pobrane z https://www.atlanticcouncil.org/blogs/ukrainealert/why-the-donbas -is-so-vulnerable-to-russian-propaganda.

Богданов, C., et. all. (2017). Соціально-психологічні чинники порушення стресостійкості дітей, що проживають у буферній зоні воєнного конфлікту на Сході України. Проблеми політичної психологї, 4 (18), 40-51. 